\title{
Morshen after Ekho i zerkalo ${ }^{1}$
}

$\mathcal{E}$ ver since the publication of his first collection of verse, Tiulen', in 1959 (with a preface by Vladimir Markov), the poet Nikolai Morshen has produced a new volume of poetry at the end of each succeeding decade. Dvoetochie came out in 1967 and Ekho i zerkalo in 1979. ${ }^{2}$ In the early 1980s poems intended for Morshen's next collection, whose title was known to be Umolkshii zhavoronok, began appearing in Russian publications in the West, among them Russkii al'manakh and Perekrestki.

Umolkshii zhavoronok is now complete, though as yet unpublished (the poet was kind enough to lend me a copy for this article). ${ }^{3}$ Unlike its three predecessors, each of which possesses an organic unity, the new collection, subtitled Dva polusbornika, consists of two sections, the first bearing the same title as the whole volume (it contains nineteen poems) and the second one called "Eretik" (eighteen poems). This last "half-collection" contains poems on topics from the Old and New Testament and Russian cultural traditions which may indeed strike some as heretical. The first half addresses itself to matters that some critics have singled out in Morshen's earlier collections as his central themes. What are some of them?

1 Originally published in Readings in Russian Modernism: To Honor Vladimir Fedorovich Markov, ed. Ronald Vroon and John E. Malmstad (Moscow: Nauka [Oriental Literature], 1993), 165-72. This essay can best be read in conjunction with the preceding one, which includes translations of titles, explains terminology, and elucidates context.-Ed.

2 Nikolai Morshen (Nikolai Nikolaevich Marchenko), Tiulen' (Frankfurt am Main: Posev, 1959); Dvoetochie (Washington, D.C.: Victor Kamkin, 1967); Ekho i zerkalo (Berkeley: Berkeley Slavic Specialties, 1979). For publication data, thematic description of Morshen's first three collections, and the poet's biography, see Simon Karlinsky, "Morshen, or a Canoe to Eternity," Slavic Review 41, no. 1 (Spring 1982): 1-18 [reprinted in the present volume].

3 Umolkshii zhavoronok was first published in its entirety in Nikolai Morshen, Sobranie stikhov, ed. O. Raevsky-Hughes (Oakland: Berkeley Slavic Specialties, 1996). See also Nikolai Morshen, Pushche nevoli: Stikhi, ed. V. V. Agenosov (Moscow: Sovetskii sport, 2000).-Ed. 
Vsevolod Setchkarev defined Morshen's "three great themes" as (1) "poetry and its materials: the word, verse [and] speech"; (2) "nature, but not in the usual sense of 'nature poetry"; and (3) "science about nature (evolution, primarily)." He continues, "It is the interconnection, the fusion, the interweaving of these three thematic strands that give Morshen's poetry its unique quality."4 G. S. Smith had the same phenomenon in mind when he wrote of "ex-Kievan Nikolai Morshen, who is preoccupied

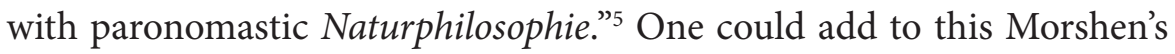
frequent insistence that the arts and sciences are ultimately children of nature in exactly the same sense as living beings are (including the germinating plants that are the dominant image of Dvoetochie and the talented birds whose song keynoted Ekho i zerkalo). So is the organic matter that forms the earth and its atmosphere.

This view is freshly reiterated in the untitled fourth poem of Umolkshii zhavoronok, which begins with the words "Ledniki i moreny ..." (Icebergs and moraines ...). Unlike the majority of this poet's work, the poem is couched in free verse. Metrical organization is rudimentary. There are a few rhymes or assonances, strategically placed where they would illustrate the point of the poem, which is that glaciers and moraines carved palpable forms long before the first sculptor, winds whistled intelligible melodies before the first musician, and sunrises and sunsets painted vivid canvases on the sky before there were painters. Only verse had to be born together with humans, "blindly / at an unknown place." The poem ends with a clearly iambic and self-rhyming line that drives home the message of the preceding stanza: "Primer-Gomer" (An example is Homer).

This poem is an example of Morshen's structural procedure of deepodrazhanie, which he launched in Ekho i zerkalo. ${ }^{6}$ The intermittent meters and the few carefully placed rhymes in the first three stanzas show the transitory quality of the art produced by inanimate matter. Meter and rhyme vanish in the fourth stanza, where human beings first appear, only to blaze forth triumphantly in the iambic and rhyming last line that signals the advent of Homer, one of the earliest human poets.

4 Vsevolod Setschkareff, "Naturwissenschaft und Poesie (Bemerkungen zur Dichtung Nikolai Moršens)," Die Welt der Slaven 27, no. 2 (1982): 235-36.

5 G. S. Smith, "Another Time, Another Place," Times Literary Supplement, 26 June 1987, 692.

6 Karlinsky, "Morshen, or a Canoe to Eternity," 12. 
In Umolkshii zhavoronok, as in Ekho i zerkalo, deepodrazhanie enables the reader not only to understand and hear the text, but also to visualize what is being described. This can be seen in the following brief poem:

\section{Стихи предлагают любому \\ Свою подъяремную грудь-}

Возможность, как по чернозему,

По лексике плуг потянуть.

Стихи обнажают не сразу

Свою подколодную стать-

Наклонность узорчатой фразой,

Чешуйчатой рифмой блистать.

Стихи открывают не многим

Свою поднебесную суть-

Способность ожить за порогом,

Из рук у тебя упорхнуть.

The central images of each of the three stanzas-the ox, the snake and the bird, respectively-are neither mentioned nor identified in the poem. Yet the standard epithets and activities associated with each of these animals cause them to materialize in the reader's mind.

This instance of deepodrazhanie is akin to other poetic procedures favored by Morshen, such as literary metamorphosis (ox turning into snake turning into bird in the cited poem); intertextual collage; paronomasia and other forms of sound organization; and, of course, the creation of neologisms, which range from simple ones (the adverb arkhimetko in the poem, "Stikhi na sluchai," where Archimedes appears in the final line) to complex ones that verge on zaum'. In "Flora i favn"-the title itself is a pun on the Russian version of "flora and fauna"- the poet takes the plant called cow wheat in English and ivan-da-mar'ia in Russian as his basic verbal model to tell an unhappy rustic love story where the traditional names of field plants are used in their nonbotanical connotations to provide the vocabulary for this narrative poem's plot.

In "Charodeika" Morshen follows the precedent of Vladimir Soloukhin's book on mushroom gathering, Tret'ia okhota, in undertaking the rehabilita- 
tion of the aspen tree. ${ }^{7}$ The aspen has been slandered in Russian folklore (its quivering leaves are said to remember Judas, who hanged himself from an aspen - which does not grow in Palestine as per Soloukhin - and werewolves can be defeated only if aspen stakes are driven through their hearts) and in literature (such as Turgenev's story "Svidanie" in Zapiski okhotnika, where the pure heroine is symbolized by a birch, while the aspen is associated with the false and pretentious butler who betrayed the girl). Unlike Soloukhin, Morshen does not deny the magical and even diabolical qualities traditionally associated with the aspen. Instead he metamorphoses the feminine-gender tree, osina, into a seductive enchantress, a doomed beauty who is then further metamorphosed into three bewitching beings from three Ukrainian tales by Gogol: rusalka (river nymph, in "Maiskaia noch"), pannochka (young lady, in both "Taras Bul'ba" and "Vii") and ved'ma (witch, the true nature of the pannochka in "Vii"). The line containing the Gogolian reference dissolves whatever little resistance the poet offered to this treeturned-into-woman. He will allow her to enter his "enchanted gaze" and thus be transformed into a poem he will compose about her.

In his essay about the poet Georgy Ivanov, Vladimir Markov defined Ivanov's style as "a mélange of colloquialism, 'music,' and quotations," adding in a footnote that "perhaps there is a law: the last man in any series resorts to quotation." 8 Different as Morshen's poetry is from Ivanov's, Markov's stylistic definition fits, oddly enough, both poets. As for the law about the last man in a series resorting to quotation, Morshen is as given to it as Ivanov, possibly even more so. Some of his poems are so saturated with quotations and/or deliberate references to other poets that their texture deserves to be called an intertextual collage. The most striking of these collages is the ten-line rhyming song at the end of the poem, "Ia svoboden, kak brodiaga ..." in Dvoetochie, in which every line is a quotation from a different Russian poet, beginning with Aleksei Khomyakov and A. K. Tolstoi and ending with two lines of Pushkin, one from "Prorok" and the other from "Besy."

7 Vladimir Soloukhin, Tret'ia okhota (Moscow: Sovetskaia Rossiia, 1968), 51-55.

8 Vladimir Markov, "Georgy Ivanov: Nihilist as Light-Bearer," in The Bitter Air of Exile: Russian Writers in the West 1922-1972, ed. Simon Karlinsky and Alfred Appel, Jr. (Berkeley: University of California Press, 1977), 146 and 150; originally published in TriQuarterly, no. 27 [Spring 1973]).

9 Morshen, Dvoetochie, 65-66. 
The following poem from Umolkshii zhavoronok is a case in which intertextuality does not attain the density of a collage, but is quite evident and striking nonetheless.

\author{
В нежном плене сладкой слепоты, \\ В плоском свете одноглазой кривды \\ Не пройдут бескормчие плоты \\ Мимо Сциллы и Харибды.
}

Нужен киль да руль и нужен глаз да глаз,

Чтобы розоперстей стали зори

И ладья не в Лету пронеслась-

В Ионическое море.

Где вода, как правда, солона,

И, как ложь, недолговечна пена,

И бесхитростная глубина

Отрезвляет постепенно.

Где волна с волною не спеша

Коротает вечность в разговоре.

Вспоминай же море, о душа,

Вспоминай (memento) море!

The first eight lines tell of the perilous passage of Odysseus and his crew between Scylla and Charybdis, once two beautiful women, who had been turned into voracious sea monsters by the vengeful gods, as recounted in the twelfth canto of the Odyssey. While hewing closely to the situation in Homer, Morshen introduced his own theme: the need for intelligence and skill to make the passage and for appropriate nautical technology to escape the two monsters. The "rafts devoid of steersmen" in line 3 cannot overcome the danger, even though the appealing adjectives nezhnom and sladkoi, and the unobtrusive but elegant alliterations of plene, ploskom and ploty (with their suggestion of waves lapping the shore) and of sladkoi slepoty might lull the reader into thinking that the danger can be escaped.

Only a craft equipped with a keel and a rudder and guided by a watchful steersman will assure that the travelers not rush into death 
(the river Lethe), but emerge into the Ionian Sea. In this Homeric ambience, the standard, even hackneyed epithet for the goddess of dawn, Eos, "the rosy-fingered," coexists without the least friction with a line from Griboedov's Gore ot uma, "nuzhen glaz da glaz" (from the maid Liza's opening monologue in act one of the play). The Griboedov quotation obviously generated the Homeric-sounding phrase, "Nuzhen kil' da rul'," that precedes it.

But as the second line of the poem serves notice, the theme is not only the nautical skill of Odysseus, but also the ability to steer one's way between truth and falsehood. The "affectionate captivity in sweet blindness" in line 1 suggests the earlier imprisonment of Odysseus by the amorous demigoddesses Calypso and Circe, which, though it was affectionate and sweet, was also debilitating. This would cause the hero to see things in the "trite light of one-eyed falsehood" of line 2, a condition likened to sailing on pilotless rafts incapable of conveying Odysseus to the Ionian Sea, revealed in the third stanza of the poem as the realm of truth.

The imagery and the vocabulary of this contest between truth and falsehood suggest certain intertextual echoes, perhaps unconscious ones, from two later poems by Osip Mandelstam. The late poetry of Mandelstam, with its deep concern with officially imposed falsehood, is highly valued by Morshen. ${ }^{10}$ We can compare Mandelstam's shestipalaia nepravda with Morshen's odnoglazaia krivda (in both cases falsehood personified by a female entity marred by physical deformity); or, in a poem of 1937 which also begins with the imagery of sailing the seas, Mandelstam's "gor'ka morei trava / Lozhnovolosaia-i pakhnet dolgoi lozh'iu” with Morshen's lines 9 and $10::^{11}$

\footnotetext{
Где вода, как правда, солона,

И, как ложь, недолговечна пена.
}

The "guileless depth that gradually sobers one up" in lines 11 and 12 marks the hero's final attainment of safety and also evokes the earlier departure of Odysseus from the island of the Sirens. After the escape from blindness and peril and the acquisition of life-supporting skills and truth

10 Karlinsky, "Morshen, or a Canoe to Eternity," 7.

11 Osip Mandel'shtam, Sobranie sochinenii v trekh tomakh, ed. G. P. Struve and B. A. Filippov, vol. 1 (Munich: Inter-Language Literary Associates, 1967), 164 and 250. 
in the first three stanzas of the poem, peace and security are reached in the fourth stanza, with its evocations of Pushkin's govor voln and Batyushkov's and Mandelstam's cozy, everyday eternity (vechnost'). But the poet does not want the hero to forget the perils and escapes that he has endured and therefore concludes the poem with the clever pun on the Russian word for sea, more, and the familiar Latin maxim memento mori.

Umolkshii zhavoronok differs from Morshen's earlier collections in the profusion of its biblical and classical allusions. They are particularly dense in the second polusbornik of the volume, "Eretik." Like Lev Tolstoi, Morshen has difficulty accepting the validity of certain New Testament miracles. The opening poem of this section, also bearing the title "Eretik," expresses doubt about the assertion in Matthew 17:20 that a mustard seed's worth of faith is sufficient to move a mountain. Such thinking, the poem implies, easily leads to burning live people for a supposed lack of faith:

\footnotetext{
Потому что, как ни скверно,

Еретик и сам постиг:

Кто сжигает-правоверный,

Кто горит, тот еретик.
}

Likewise, "Predpaskhal'noe" points out the injustice committed by Christ (as told in Matthew 21:19 and Mark 11:13-14) in cursing a fig tree and causing it to wither for not bearing any fruit. The time, the poet points out, was Easter and the tree could not have produced fruit before having blossomed.

Even more attractively heretical is the poem "Stikhi i stikhii," where not only is a poet (stikhotvorets) casually equated with the Creator (Tvorets stikhii), but the Book of Genesis is contaminated with Greek and Roman classics. The creation of the mountains is equated with the creation of "Exegi monumentum" by Horace (in its Pushkin redaction and with the added alliterative bonus of gory and Goratsii). The creation of amphibians, birds, insects, and clouds is likened to Aristophanes's choice of titles for his comedies:

Летели, плыли по-аристофаньи

Лягушки, птицы, осы, облака. 
Finally, the Serpent in the Garden of Eden is said to be an earlier incarnation of Ovid, the author of Ars amandi:

Где, в ироническом являясь виде,

Пел языком стихов (или стихий?)

Любви искусство райский пра-Овидий,

Накликавший изгнанье змий.

Let us now return to Vladimir Markov's remark about the last man in a series (the one who quotes). As early as 1974, Leonid Rzhevsky pointed out that Morshen's poetic language was moving in the direction of the verbally-conscious art of Russian Futurists of the early twentieth century. Rzhevsky saw this new fusion of sonority and meaning in Morshen's later poetry as something derived "from euphony and from philosophic meditations and from Pasternak and from Khlebnikov, but most of all from the exceptional talent of the poet himself." ${ }^{\prime 2}$ When Lazar Fleishman spoke of the same aspect of Morshen's poetry at a conference on the literature of the Russian emigration, ${ }^{13}$ the older scholar Nikolai Andreev insisted that Morshen's poetic evolution "did not happen in a vacuum" and that its cause was that "there lives in America Morshen's friend, the remarkable literary scholar, Professor Vladimir Markov, who wrote, as you well know, a splendid book on the Futurists and published many things in the journals." 14

Morshen may well be the last poet to continue the traditions of Russian "Verbalism" (Aleksei Remizov's expression), because none of today's younger poets, not even the ultramodern Meta-metaphorists, such as Ivan Zhdanov, Aleksei Parshchikov and the gifted Nina Iskrenko, explore the possibilities of slovotvorchestvo in such depth as Morshen. There are many poems one could cite from Umolkshii zhavoronok to illustrate his varied uses of korneslovie and quasi-zaum'. In the humorous "Kva-s," the Russian version of the frogs' croaking, $k v a$, the national soft drink kvas, the

12 Leonid Rzhevskii, “Strofy i 'zvony’ v sovremennoi russkoi poezii,” Novyi zhurnal, no. 115 (1974): 137.

13 G. Nivat, ed., Odna ili dve russkikh literatury? Mezhdunarodnyi simpozium, sozvannyi Fakul'tetom slovesnosti Zhenevskogo universiteta i Shveitsarskoi akademiei Zheneva, 13-14-15 aprelia 1978 (Lausanne: l'Age d'Homme, 1981), 63-76.

14 Ibid., 81-82. 
expression kvasnoi patriotizm (jingoism), and the national favorite source of quotations (Griboedov again) are all combined to suggest that life during what is now called "the period of stagnation" was as monotonous and parochial as the croaking of frogs in a swamp. The interrelated poems "Azbuka kommunizma" and "Azbuka demokratii" use the modern Russian and Old Russian alphabets to bring out in an unexpected way the contrast between freedom and oppression, a theme present in all Morshen's collections, beginning with Tiulen'.

"Chelovek-nevidimka," couched in the rare meter of anapestic pentameter (with a few lapses into dol'nik), states the seldom-noticed fact that history remembers those who engaged in violence or were victimized by it, but forgets those who changed the world with their decency and good deeds. Thus, everyone knows about the Decembrists who were hanged, but the names of the Decembrists who had granted freedom to their serfs are forgotten:

Ни строки, ни доски, никоторого нет им признанья!

Но усмешкою циник отторгнет мое восклицанье.

Here, as in the rest of this poem, the all-but-invisible internal rhyme is formed when the words nikotorogo net are echoed across the word boundary in the last syllable of tsinik and the first two syllables of ottorgnet, illustrating the historical invisibility of the people in question.

Morshen's poetry is so rich and varied that one is tempted to describe and analyze every poem of Umolkshii zhavoronok. To resist this temptation, I would like to conclude by quoting the densely neologistic poem "Raiskoe utro" in its entirety. The poem takes place in the Garden of Eden before Adam was given the power to name things. At this stage nothing has a name yet and the poet is obliged to describe everything with neologism suggestive of function or typical form of motion. The profusion of affectionate diminutives conveys Adam's (and the poet's) delight at discovering all these unfamiliar entities. To facilitate comprehension, it can be stated that lines 1-4 describe a stream; lines 5-6, a fluffy tree branch; lines 7-8, a songbird; lines 9-10, dew on leaf stems; lines 11-12, bees and flowers; line 13, huge coniferous trees; line 14, a clear sky. Lines 15-16 are self-explanatory. A particularly rich neologism is zelenitochka in line 9. Combining the words for green and thread, it well conveys the 
image of leaf stems. But also, because selenit is the word used in Russian science fiction in the meaning of moon dweller, zelenitochka also suggests a little lunar girl:

\section{Райское утро}

Течет себе зеркалинка, Струилка, омывалочка, По-омутам-молчалинка, По-отмелям-журчалочка.

Пушистой машет кисточкой Приветка-свежелисточка, Щебечет свиристаловка, Порх-порх-перелеталовка.

На каждой зелениточке Сверкалки, водослиточки, Для каждой прижужжальницы Открылись расцветальницы.

Иглогиганты храмовы.

Высокосинь блистательна.

И утро так адамово

Так первоназывательно.

Morshen's fourth collection of poems (or two half-collections, as he prefers) is further testimony to this astonishing poet's ever-growing profundity and skill. In conversation he stated repeatedly that Umolkshii zhavoronok was his last book and that he did not intend to write any more verse. This would disappoint the huge new audience he has gained through recent publications of his work in Russia. But even as his oeuvre now stands, the four volumes that comprise it are clearly one of the treasures of twentieth-century Russian poetry. 